\title{
KARAKTERISTIK COKELAT SPREAD DENGAN PENAMBAHAN OLEOGEL DARI OLEOGATOR LEMAK KAKAO
}

\author{
Chocolate Spread Characteristics with Oleogel Addition \\ from Cocoa Butter Oleogator
}

\author{
Alfrida Lullung Sampebarra, Khaerunnisa, Eky Yenita Ristanti, dan Dyah Wuri Asriati \\ Balai Besar Industri Hasil Perkebunan Makassar (BBIHP) \\ Jalan prof. Abdurahman Basalamah No.28 makassar 90231 \\ E-mail : alfridallullung@yahoo.com
}

\begin{abstract}
The purpose of this study was to apply oleogels with cocoa fat oleogators on chocolate spread. Chocolate spread are made from melted chocolate bars with formula BS3, PS3, BK3, PK3, $B C B S$, and PCBS which contain oleogels from palm oil, cocoa fat, and soybean oil. The results showed that six chocolate spread formulations contain 23 types of fatty acids (fatty content) with each chemical characteristic called fatty acids value namely Cis fatty acids, Cis-10-Heptadecanoic Acid, C17:1, Cis11,14-Eicosedienoic Acid, C20: 2, Cis-8,11,14-Eicosetrienoic Acid, C20:3n6 in BK3 and PK3 products but not in BS3, PS3, BCBS, and PCBS. While Cis-13.16-Docosadienoic Acid C22:2 fatty acids are found in chocolate products topped with PK3 and BS3 but are not found in BK3, BS3, PS3, BCBS, and PCBS. Analysis of As, Sn, Cd, and Hg metal contamination in chocolate spread products showed smaller average value or undetectable metal contamination based on SNI of Chocolate and Chocolate Products. The best results of color and texture sensory tests are BCBS formula with score of 5.35 and PCBS with score of 5.45 with softer textures, more shiny surfaces and better color appearance on product surface.
\end{abstract}

Keywords: application, chocolate, chocolate spread, cocoa fat, oleogel.

\begin{abstract}
Abstrak: Tujuan penelitian ini adalah mengaplikasikan oleogel dengan oleogator lemak kakao pada produk cokelat spread. Cokelat spread dibuat dari cokelat batang yang dilelehkan dengan formula BS3, PS3, BK3, PK3, BCBS, dan PCBS yang mengandung oleogel dari minyak sawit, lemak kakao dan minyak kedelai. Hasil penelitian menunjukkan bahwa dari keenam formulasi cokelat spread yang dihasilkan mengandung 23 jenis asam lemak (fatty acid dan fatty content) dengan masing masing karakterisik kimia yaitu nilai asam lemak diantaranya asam lemak Cis, Cis-10-Heptadecanoic Acid, C17:1, Cis-11,14-Eicosedienoic Acid, C20:2, Cis-8,11,14-Eicosetrienoic Acid, C20:3n6 pada produk BK3 dan PK3 tetapi tidak terdapat pada BS3, PS3, BCBS, dan PCBS. Sedangkan asam lemak Cis13,16-Docosadienoic Acid C22:2 terdapat pada produk cokelat spread PK3 dan BS3 tetapi tidak terdapat pada BK3, BS3, PS3, BCBS dan PCBS. Hasil analisa cemaran logam As, Sn, Cd, dan Hg pada produk cokelat spread yang dihasilkan menunjukkan nilai rata-rata yang lebih kecil atau tidak terdeteksi adanya cemaran logam berdasarkan SNI Cokelat dan Produk Cokelat. Hasil terbaik dari uji sensori warna dan tekstur yaitu pada formula BCBS dengan skor 5,35 dan PCBS dengan skor 5,45 dengan tekstur yang lebih lembut, permukaan lebih mengkilap dan penampakan warna pada permukaan produk yang lebih bagus.
\end{abstract}

Kata Kunci : aplikasi, cokelat, cokelat spread, lemak kakao, oleogel.

\section{PENDAHULUAN}

Produksi kakao nasional cenderung meningkat setiap tahunnya. Pada tahun 2010 total produksi kakao Indonesia mencapai 831.919 ton, pada tahun 2011 turun 712 ton dan pada tahun 2012 meningkat kembali menjadi 740.513 ton. Hasil produksi biji kakao selama ini umumnya diekspor dalam bentuk biji kering dan sebagian diekspor dalam bentuk kakao olahan seperti lemak kakao, pasta kakao, bubuk kakao, dan bungkil kakao.

Rendahnya produksi kakao olahan di Indonesia disebabkan oleh beberapa kendala antara lain masih kurangnya pengetahuan masyarakat tentang teknologi pengolahan kakao, belum berkembangnya teknologi diversifikasi produk kakao serta ketersediaan peralatan dan mesin yang sulit terjangkau. Salah satu produk pangan 
berbahan cokelat atau bubuk cokelat adalah produk cokelat spread yang merupakan salah satu produk olahan kakao yang sudah banyak diproduksi di Indonesia oleh industri besar namun harganya relatif mahal, sehingga sulit terjangkau oleh masyarakat ekonomi menengah ke bawah.

Salah satu produk olahan lemak cokelat dan bubuk cokelat adalah cokelat spread atau dikenal secara umum yaitu sebagai selai coklat yang terbuat dari pasta cokelat sebagai olesan pada permukaan roti. Cokelat spread juga mengandung kakao, minyak, susu, dan tambahan serta pengawet makanan. Pada umumnya, cokelat spread terbuat dari bubuk kakao yang merupakan hasil samping dari lemak kakao. Cokelat spread atau lebih umum dikenal dengan selai cokelat adalah campuran yang bersifat setengah padat yang terdiri dari tidak kurang dari 45 bagian bubur dan 55 bagian berat gula yang dikentalkan sampai kadar zat padat terlarut menjadi 65\% (Ginting, 2011).

Isyanti, et al. (2012) telah melakukan penelitian mengenai cokelat spread berbasis sawit dengan hasil terbaik secara organoleptik yaitu cokelat spread dengan komposisi olein sawit $(60 \%)$ dan lemak cokelat (40\%). Proses pembuatan cokelat spread yang dilakukan adalah mencampurkan fraksi air (susu, skim, gula halus, dan kalium sorbat) dengan fraksi lemak (olein sawit, lemak cokelat, dan bubuk cokelat serta lesitin) menggunakan mixer di atas waterbath pada suhu $90-100^{\circ} \mathrm{C}$ selama 15 menit, kemudian dimasukan ke dalam jar dan dipasteurisasi pada suhu $70^{\circ} \mathrm{C}$ selama 15 menit.

Beberapa penelitian tentang cokelat spread telah dilakukan oleh El-Hadad, et al. (2011) dan Isyanti, et al. (2012) dalam pemanfaatan turunan minyak sawit berupa RBDPO dan RBDPS atau campuran keduanya sebagai bahan subtitusi lemak cokelat untuk menghasilkan produk cokelat spread dengan metode blending. Syarat cokelat spread yang baik adalah mudah dioleskan dan mempunyai aroma dan rasa buah asli. Pada pembuatan selai cokelat atau cokelat spread umumnya menggunakan penambahan bubuk cokelat sebagai pengganti bahan utama untuk memberikan rasa dan aroma dari buah kakao asli (Deannisa, et al., 2014).

Menurut penelitian Arie, et al. (2015), produk cokelat spread atau selai coklat sangat digemari oleh kalangan masyarakat umum terutama anak-anak dan berfungsi sebagai olesan yang sering dioles pada roti tawar. Selai cokelat mengandung kakao bubuk, susu, dan minyak lemak (shortening) yang dapat memperbaiki mutu tekstur produk selai cokelat. Salah satu komponen yang paling penting dalam pembuatan produk olesan seperti cokelat spread adalah lemak akan memberikan efek seperti mentega, memperkaya rasa, memberikan tekstur yang lembut serta akan meningkatkan patabilitas roti dan kue seperti meminyaki roti pada saat dimakan, selain itu sebagai sumber vitamin dan asam lemak esensial yang memberikan flavor pangan (Winarno, 1997).

Agar produk cokelat spread berbasis sawit yang dihasilkan menjadi lebih bernutrisi maka perlu dilakukan penambahan zat gizi seperti salah satu penelitian Ristanti, et al. (2017) tentang oleogel dari minyak sawit dan minyak kedelai yang dapat diaplikasikan pada produk pangan seperti cokelat spread. Oleogel yang terbuat dari minyak sawit dan minyak kedelai mengandung asam-asam lemak yang bermanfaat bagi tubuh seperti asam palmitat, asam oleat, asam stearat, dan asam linoleat. Minyak sawit mempunyai komposisi asam lemak jenuh dengan proporsi yang seimbang. Berdasarkan komposisi asam lemak jenuh dan tak jenuh yang seimbang maka secara ideal bisa menjadi produk oleogel yang dapat diaplikasikan ke dalam produk makanan sehingga dapat menjadi salah satu alternatif untuk meningkatkan mutu produk cokelat spread atau selai cokelat dengan tesktur yang lebih baik (Hariyadi, 2014).

\section{METODOLOGI}

\section{Bahan dan Alat}

Bahan yang digunakan pada penelitian yaitu susu cair, cokelat batang dari bahan 
bubuk dengan menggunakan oleogel dari minyak kedelai (BK3) dan pasta (PK3), bubuk dengan oleogel dari minyak sawit (BS3) dan pasta (PS3), bahan dan pasta (PCBS) bubuk dengan menggunakan Cocoa Butter Substitute (CBS) pada kode (BCBS) dan bahan pasta (PCBS), aquadest, kalium sorbat sebagai pengawet, dan pereaksi uji asam lemak trans. Peralatan yang digunakan terdiri dari timbangan, wadah atau baskom stainless, spatula, kompor listrik, steambath, oven, alat GC, dan botol steril sebagai kemasan.

\section{Waktu dan Tempat Penelitian}

Penelitian dilakukan pada bulan Maret hingga Mei 2018 di Laboratorium BBIHP Makassar dan Laboratorium IPB Bogor. Metode penelitian mencakup pembuatan cokelat spread dari cokelat batang, dan aplikasi oleogel minyak sawit dan minyak kedelai pada cokelat batang dan pengujian mutu kimia dari karakteristik produk cokelat spread.

\section{Pembuatan Cokelat Spread}

Tahap pembuatan produk selai coklat (cokelat spread) seperti yang terlihat pada Gambar 1 yaitu menimbang bahan, melelehkan coklat batang sebanyak 500 gram dari formula BS3, PS3, BK3, PK3, BCBS, dan PCBS. Bahan-bahan tersebut ditambahkan susu cair sebanyak $250 \mathrm{ml}$ dan kalium sorbat sebanyak 0,2 gram, lalu diaduk rata hingga homogen di atas waterbath, didinginkan dan segera dikemas dalam botol kaca bertutup.

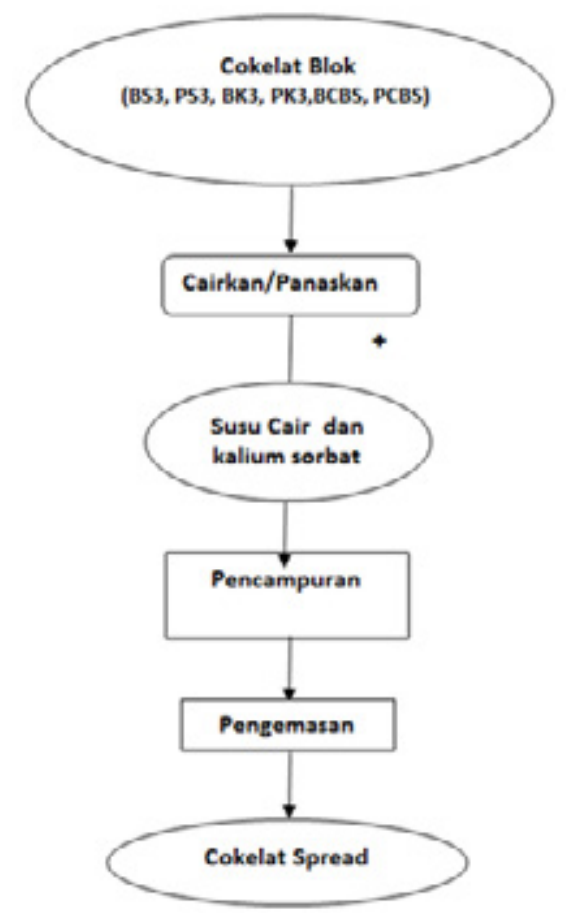

Gambar 1. Proses Pembuatan Cokelat Spread

Formulasi Cokelat Batang BS3, PS3, BK3, PK3, BCBS, dan PCBS

Produk cokelat batang dengan formula BS3, PS3, BK3, PK3, BCBS, dan PCBS (Ristanti, et al., 2017) sebagai berikut:

Oleogel yang digunakan yaitu oleogel yang dibuat dengan formulasi $\mathrm{S} 3, \mathrm{~K} 3$, dan CBS yaitu S3:minyak sawit 90\%:lemak kakao 3\%:beeswax 7\% dan K3:minyak kedelai 90\%:lemak kakao 3\%:beeswax $7 \%$. Masing-masing dibuat dalam 500 $\mathrm{ml}$.CBS sediaan dan shortening (mentega putih) yang langsung ditambahkan pada pembuatan cokelat batang dan selai cokelat. Pembuatan cokelat batang menggunakan bahan oleogel S3 dan K3 baik dari pasta maupun bubuk cokelat masing masing $2 \mathrm{~kg}$, gula $2 \mathrm{~kg}$, garam $4 \mathrm{gr}$, lesitin $30 \mathrm{gr}$, dan vanili $8 \mathrm{gr}$. Adonan dihaluskan melalui alat conching selama 4 jam pada suhu 50 ${ }^{\circ} \mathrm{C}$ kemudian dicetak dengan alat cetakan cokelat. Cokelat batang yang telah tercetak kemudian dilelehkan untuk menghasilkan cokelat spread.

Parameter uji yang digunakan pada penelitian yaitu pengujian fatty acid, fatty content dengan metode uji menggunakan gas chromatography, warna, tekstur, dan 
uji cemaran logam menggunakan Atomic Absorbtion Spectrophotometry (AAS).

\section{HASIL DAN PEMBAHASAN}

Hasil uji yang diperoleh menunjukkan bahwa cokelat spread dengan formulasi BS3, PS3, BK3, PK3, BCBS, dan PCBS (Tabel 1) mengandung senyawa-senyawa asam lemak bebas.

Hasil uji menunjukkan bahwa cokelat spread yang dihasilkan (Tabel 1) mengandung 23 jenis asam lemak. Jenis asam lemak yang tinggi pada cokelat spread dengan oleogel dari minyak sawit adalah Oleic Acid, disusul C18, Palmitic Acid, C16:0, Stearic Acid, C18:0, dan Linoleic Acid, C18. Sedangkan kandungan asam lemak yang tinggi pada cokelat spread dengan oleogel dari minyak kedelai adalah Linoleic Acid C18:2n6c,disusul Oleic Acid, C18:1n9c, Palmitic Acid, C16:0, dan Stearic Acid, C18:0. Demikian juga kandungan asam lemak yang tinggi dari cokelat spread dengan lemak CBS adalah Lauric Acid, C12:0, disusul Stearic Acid, C18:0, Palmitic Acid, C16:0, dan Oleic Acid, C18:1n9c. Perbedaan kadar asam lemak dari tiap jenis asam lemak pada cokelat spread dipengaruhi oleh jenis minyak atau lemak pada oleogel yang digunakan dalam pembuatan cokelat spread.

Tabel 1 menunjukkan adanya nilai asam lemak yaitu asam lemak Cis-10Heptadecanoic Acid, C17:1, Cis-11,14Eicosedienoic Acid, C20:2, Cis-8,11,14Eicosetrienoic Acid, C20:3n6 pada produk BK3 dan PK3 tetapi tidak terdapat pada BS3, PS3, BCBS, dan PCBS. Sedangkan asam lemak Cis-13,16-Docosadienoic Acid C22:2 terdapat pada produk cokelat spread PK3 dan BS3 tetapi tidak terdapat pada BK3, BS3, PS3, BCBS, dan PCBS. Namun nilai asam oleat tertinggi rata-rata berkisar 35 hingga $24 \%$ pada cokelat spread BK3, PS3, dan BS3 yang mengandung oleogel dari minyak kedelai. Asam lemak adalah asam monokarboksilat berantai lurus yang terdapat di alam sebagai ester di dalam molekul lemak atau trigliserida. Hasil hidrolisis trigliserida akan menghasilkan asam lemak jenuh dan tak jenuh. Asam lemak tidak jenuh memilki ikatan rangkap yang terdapat pada minyak dapat berada dalam dua bentuk yakni isomer cis dan trans. Jumlah asam lemak trans dan cis dapat mengikut di dalam makanan berlemak terutama margarin dan selai akibat dari proses pengolahan yang diterapkan seperti hidrogenasi pada saat pemanasan dengan suhu tinggi (Jansen dan Sanggam, 2002).

Tabel 1 juga menunjukkan adanya bentuk cis pada produk cokelat oles (BK3, PS3, dan BS3) yang dihasilkan. Hal ini disebabkan karena oleogel dari minyak sawit dan minyak kedelai tidak mengalami hidrogenasi tetapi hanya dilakukan proses pengadukan untuk menyatukan dispersi minyak dan lemak kakao dengan alat pengaduk Ultra Turrax. Menurut Murry et al. (2005), asam lemak trans dan cis merupakan golongan asam lemak tak jenuh dengan trans isomer yang mengacu pada konfigurasi ikatan rangkap karbon yang berasal dari minyak nabati yang mengalami proses pemadatan melalui teknik pemanasan atau teknik hidrogenasi parsial. Selain itu, minyak sayur (minyak kedelai, jagung, dan biji bunga matahari) mengadung sekitar $87-93 \%$ asam lemak tak jenuh yang sangat peka terhadap pemanasan yang dapat memicu terbentunya asam lemak trans maupun cis dari suatu senyawa lemak dan minyak (Sartika, 2008) 
Tabel 1. Hasil Pengujian Fat Content dan Fatty Acid Cokelat Spread

\begin{tabular}{|c|c|c|c|c|c|c|c|}
\hline \multirow{2}{*}{ No. } & \multirow{2}{*}{ Parameter Uji } & \multicolumn{6}{|c|}{$\begin{array}{l}\text { Hasil Uji } \\
(\% \mathrm{w} / \mathrm{w})\end{array}$} \\
\hline & & BK3 & PK3 & BS3 & PS3 & BCBS & PCBS \\
\hline & Fat Content & 24.69 & 23.38 & 21.52 & 22.56 & 14.52 & 22.63 \\
\hline & Fatty Acid & & & & & & \\
\hline 1 & Caproic Acid, C6:0 & 0.18 & 0.19 & 0.16 & 0.17 & 0.30 & 0.29 \\
\hline 2 & Caprillic Acid, C8:0 & 0.13 & 0.12 & 0.13 & 0.13 & 2.28 & 2.13 \\
\hline 3 & Capric Acid, C10:0 & 0.30 & 0.27 & 0.28 & 0.28 & 2.28 & 2.14 \\
\hline 4 & Undecanoic Acid, C11:0 & 0.03 & 0.03 & 0.03 & 0.03 & 0.02 & 0.03 \\
\hline 5 & Lauric Acid, C12:0 & 0.55 & 0.47 & 0.61 & 0.54 & 33.62 & 29.58 \\
\hline 6 & Myristic Acid, C14:0 & 1.51 & 1.35 & 1.90 & 1.77 & 1.81 & 10.28 \\
\hline 7 & Myristoleic Acid, C14:1 & 0.12 & 0.11 & 0.11 & 0.10 & 0.10 & 0.11 \\
\hline 8 & Pntadcanoic Acid, C15:0 & 0.14 & 0.13 & 0.15 & 0.14 & 0.12 & 0.13 \\
\hline 9 & Palmitic Acid, C16:0 & 17.91 & 18.01 & 31.80 & 32.41 & 13.87 & 16.77 \\
\hline 10 & Palmitoleic Acid, C16:1 & 0.32 & 0.31 & 0.35 & 0.34 & 0.23 & 0.26 \\
\hline 11 & $\begin{array}{l}\text { Heptadecanoic Acid, } \\
\text { C17:0 }\end{array}$ & 0.20 & 0.20 & 0.18 & 0.19 & 0.13 & 0.16 \\
\hline 12 & $\begin{array}{l}\text { Cis-10-Heptadecanoic } \\
\text { Acid, C17:1 }\end{array}$ & 0.11 & 0.05 & 0.04 & 0.04 & 0.02 & 0.03 \\
\hline 13 & Stearic Acid, C18:0 & 12.46 & 12.92 & 11.26 & 13.77 & 17.92 & 20.34 \\
\hline 14 & Elaidic Acid, C18:1n9t & - & - & & & 0.84 & 0.79 \\
\hline 15 & Oleic Acid, C18:1n9c & 24.81 & 23.82 & 34.69 & 35.64 & 9.31 & 13.15 \\
\hline 16 & Linoleic Acid, C18:2n6c & 35.20 & 32.26 & 8.74 & 8.18 & 1.08 & 1.45 \\
\hline 17 & Arachidic Acid, C20:0 & 0.44 & 0.45 & 0.38 & 0.45 & 0.28 & 0.40 \\
\hline 18 & Linoleic Acid, C18:3n3 & 3.35 & 3.01 & 0.30 & 0.29 & 0.11 & 0.16 \\
\hline 19 & $\begin{array}{l}\text { Cis-11,14-Eicosedienoic } \\
\text { Acid, C20:2 }\end{array}$ & 0.16 & 0.15 & 0.18 & 0.18 & 0.04 & 0.05 \\
\hline 20 & Behenic Acid, C22:0 & 0.33 & 0.31 & 0.08 & 0.10 & 0.06 & 0.07 \\
\hline 21 & $\begin{array}{l}\text { C i s - 8, } 11,14- \\
\text { Eicosetrienoic } \\
\text { C20:3n6 }\end{array}$ & 0.04 & 0.05 & & - & - & - \\
\hline 22 & Tricosanoic Acid, C23:0 & 0.04 & 0.03 & 0.02 & 0.02 & 0.02 & 0.02 \\
\hline 21 & 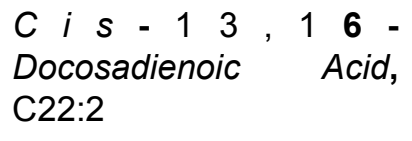 & - & 0.02 & 0.02 & - & - & - \\
\hline \multirow[t]{2}{*}{23} & Lignoceric Acid, C24:0 & 0.13 & 0.12 & 0.08 & 0.08 & 0.05 & 0.06 \\
\hline & Fatty Acid Total & 98.45 & 94.38 & 91.48 & 94.84 & 94.25 & 98.40 \\
\hline
\end{tabular}

Menurut Sartika (2008), kandungan lemak dan komposisi asam lemak dalam kedelai dipengaruhi oleh varietas dan keadaan iklim tempat tumbuh. Lemak kasar terdiri dari trigliserida sebesar 90-95\%. Sedangkan sisanya adalah fosfatida, asam lemak bebas, sterol, dan tokoferol. Minyak kedelai mempunyai kadar asam lemak jenuh sekitar $15 \%$ sehingga sangat baik sebagai pengganti lemak dan minyak yang memiliki kadar asam lemak jenuh yang tinggi seperti mentega dan lemak babi. Hal ini berarti minyak kedelai sama seperti minyak nabati lainnya yang bebas kolesterol. Asam lemak dalam minyak kedelai sebagian besar terdiri dari asam lemak esensial yang sangat 
dibutuhkan oleh tubuh. Komposisi kimia dan sifat fisiko-kimia minyak kedelai yaitu mengandung asam lemak tidak jenuh (85\%) yang terdiri dari asam linoleat $15-64 \%$, asam oleat $11-60 \%$, asam linolenat $1-12 \%$, asam arachidonat $1,5 \%$, dan asam lemak jenuh (15\%) yang terdiri dari asam palmitat $7-10 \%$, asam stearat $2-5 \%$, asam arschidat $0,2-1 \%$, asam laurat $0-0,1 \%$ (Hariyadi, 2014).

Nilai gizi asam lemak esensial dalam minyak dapat mencegah timbulnya atherosclerosis atau penyumbatan pembuluh darah. Kegunaan minyak kedelai yang sudah dimurnikan dapat digunakan untuk pembuatan minyak salad, minyak goreng (cooking oil) serta untuk segala keperluan pangan. Lebih dari $50 \%$ pangan dibuat dari minyak kedelai, terutama margarin dan shortening. Hampir $90 \%$ dari produksi minyak kedelai digunakan di bidang pangan dan dalam bentuk telah dihidrogenasi karena minyak kedelai mengandung lebih kurang 85\% asam lemak tidak jenuh (Bani, 2018).

Pengaruh asam lemak trans dan cis terhadap kesehatan dapat menimbulkan berbagai penyakit. Berdasarkan penelitian epidemiologis, trans fatty acid (TFA) atau asam lemak trans dapat menimbulkan resiko dan pengaruh negatif karena dapat menaikkan kadar LDL dalam darah, menimbulkan efek kolesterol yang tinggi, menyebabkan penyakit jantung, mengganggu metabolisme penglihatan pada mata, dan pembengkakan dinding jantung (Ovesen, et al., 1998).

Konsumsi asam lemak trans yang berlebihansangatberbahayabagikesehatan. Word Health Organization (WHO) dan Food and Agriculture Organization (FAO) tahun 2010 memberikan batasan penggunaan asupan lemak trans pada makanan yaitu kurang dari $1 \%$ dari asupan energi secara keseluruhan. WHO dan FAO mendesak industri makanan untuk mengurangi jumlah asam lemak trans pada produk yang diproduksinya. Indonesia mencantuman asam lemak trans dalam label informasi produk makanan. Nilai gizi belum diwajibkan tetapi jika diklaim bebas dari asam lemak trans harus mengandung tidak lebih dari 0,1 $\mathrm{g} / 100 \mathrm{~g}$ untuk bentuk padat dan $0,1 \mathrm{~g} / 100 \mathrm{ml}$ dalam bentuk cair (BPOM, 2011).

Hasil uji cemaran logam As, Sn, Cd, dan $\mathrm{Hg}$ pada produk cokelat spread dengan formulasi BS3, PS3, BK3, PK3, BCBS, dan PCBS disajikan pada Tabel 2. Nilai rata-rata cemaran logam yang diperoleh sangat kecil atau lebih kecil dan bahkan tidak terdeteksi adanya cemaran logam berat pada produk. Pembuatan cokelat spread banyak menggunakan wadah dari stainless steel dan sumber cemaran logam diduga berasal dari proses yang digunakan sehingga perlu dianalisa cemaran logamnya.

Cemaran logam pada bahan pangan dapat berasal dari udara dan air serta dari bahan yang digunakan pada saat mengolah dan menyajikan makanan. Menurut Arie, et al., (2015), logam akan terakumulasi pada jaringan tubuh dan dapat menimbulkan keracunan pada manusia. Proses pembuatan cokelat spread pada umumnya dilakukan dengan menggunakan peralatan yang terbuat dari logam. Selama proses pengolahan, terjadi gesekan baik antar komponen peralatan maupun antara peralatan dengan bahan baku (Daming dan Mamang, 2014). Tabel 2 menunjukkan bahwa cemaran logam pada produk cokelat spread dari keenam formula (BS3, PS3, BK3, PK3, BCBS, dan PCBS) masing-masing memenuhi standar mutu SNI Cokelat dan Produk Cokelat karena nilainya sangat kecil atau tidak terdeteksi (BSN, 2014). Hal ini disebabkan karena pada saat proses pembuatan cokelat spread waktu kontak penggunaan peralatan berbahan logam tidak berlangsung lama sehingga kontaminan cemaran logam tidak memungkinkan untuk mencemari produk (Daming dan Mamang, 2014). 
Tabel 2. Hasil Pengujian Kadar Cemaran Logam Cokelat Spread

\begin{tabular}{llllllll}
\hline & \multirow{7}{*}{ No. } & Parameter Uji & \multicolumn{7}{c}{$\begin{array}{c}\text { Hasil Uji } \\
(\mathbf{m g} / \mathbf{k g})\end{array}$} \\
\cline { 3 - 8 } & & BK3 & PK3 & BS3 & PS3 & BCBS & PCBS \\
\hline 1. & Arsen (As) & $<0.007$ & $<0.007$ & $<0.007$ & $<0.007$ & $<0.007$ & $<0.007$ \\
2. & Stannum $(\mathrm{Sn})$ & $<1.5$ & $<1.5$ & $<1.5$ & $<1.5$ & $<1.5$ & $<1.5$ \\
3. & Cadmium (Cd) & $<0.08$ & $<0.08$ & $<0.08$ & $<0.08$ & $<0.08$ & $<0.08$ \\
4. & Mercury $(\mathrm{Hg})$ & $<0.003$ & $<0.003$ & $<0.003$ & $<0.003$ & $<0.003$ & $<0.003$ \\
\hline
\end{tabular}

\section{Warna}

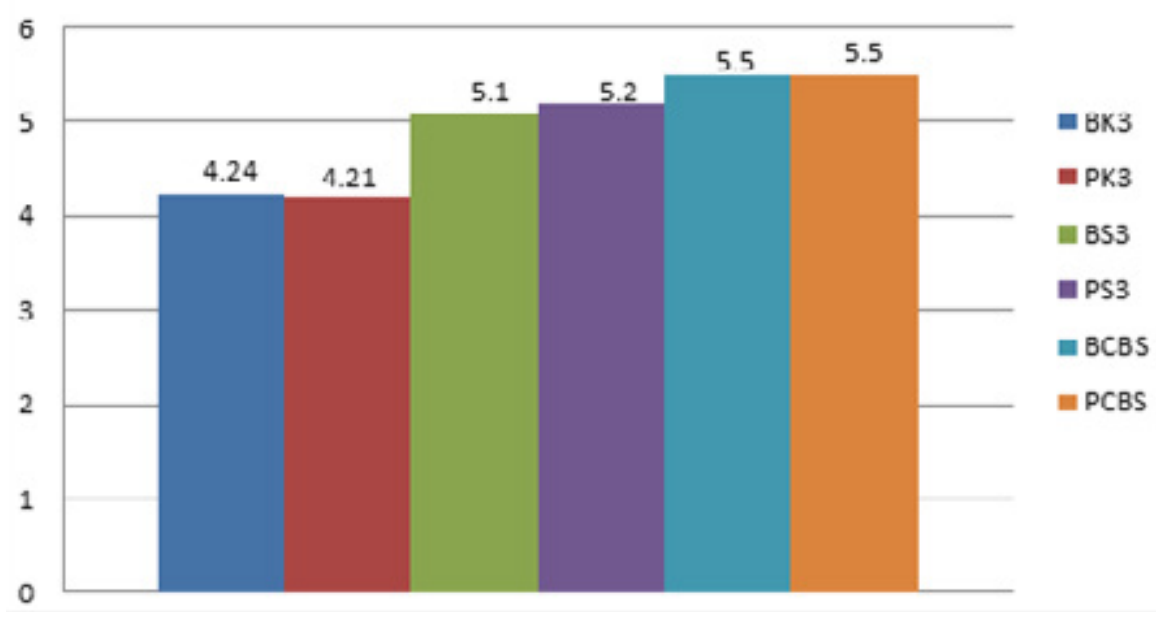

Gambar 2. Histogram Skor Keberterimaan Warna Produk Cokelat Spread dengan Penambahan Oleogel

\section{Warna}

Pengujian sensori terhadap cokelat spread (selai cokelat oleogel) memperlihatkan hasil yang tidak berbeda nyata terhadap warna dan secara keseluruhan keadaan produk dapat diterima. Hasil penilaian pada produk cokelat spread dengan formula BK3, PK3, BS3, PS3, BCBS, dan PCBS pada Gambar 2 berkisar 4,21 hingga 5,5 yang berarti rata-rata panelis memberikan respon suka hingga sangat suka. Pada uji organoleptik, panelis memberikan penilaian tertinggi pada produk cokelat spread formula BCBS dan PCBS sebagai pembanding menunjukkan nilai sangat suka pada skor 5,5. Hal ini disebabkan karena pada formula BCBS dan PCBS yang menggunakan CBS dari lemak minyak sawit menghasilkan produk cokelat yang lebih lembut dan mengkilat sehingga penampakan warna pada permukaan lebih bagus. Sedangkan pada formula BS3 dan PS3 (Gambar 2) menunjukkan nilai sensori 5,1 dan 5,2 yang hampir sama dengan BCBS dan PCBS yang memperlihatkan warna yang lebih bagus dan sangat disukai. Hal ini disebabkan karena pada formula yang digunakan adalah bahan oleogel campuran minyak sawit dengan lemak kakao serta penambahan beeswax yang komposisi kandungan asam lemaknya hampir sama dengan CBS sebagai pemanding. Menurut Marangoni dan Garti (2011), minyak kedelai dan minyak sawit mempunyai rasa yang natural dan memberikan efek warna dan aroma pada pangan yang tidak merusak rasa dan warna alami dari pangan yang diolah.

\section{Tekstur}

Tekstur adalah bagian dari sifat organoleptik pada produk. Faktor yang dapat mempengaruhi baik tidaknya produk cokelat 
yang dihasilkan yaitu pada penghalusan dan pencampran bahan yang digunakan serta ada tidaknya pengemulsi (Minifie, 1999). Bahan yang tidak halus dan tidak tercampur rata akan menyebabkan tekstur yang kasar. Hasil uji organoleptik tekstur cokelat spread dengan penambahan oleogel minyak sawit dan minyak kedelai (Gambar 3) menunjukkan bahwa nilai rata-rata terhadap tekstur cokelat spread yang dihasilkan yaitu berkisar antara 4,1 hingga 5,45 yang berarti umumnya panelis memberikan tanggapan suka dan sangat suka terhadap produk cokelat spread dengan penambahan oleogel yang dihasilkan. Penilaian tertinggi terhadap tekstur pada produk cokelat spread formula BCBS dengan skor 5,35 dan PCBS dengan skor 5,45 dengan tekstur yang lebih lembut dan permukaan lebih mengkilap. Hal ini disebabkan karena pada formula ini menggunakan bahan oleogel dari campuran minyak sawit dan lemak kakao dengan penambahan beeswax yang komposisi kandungan asam lemaknya hampir sama dengan CBS sebagai pemanding dan komposisi asam lemak tidak jenuh pada minyak sawit dan minyak kedelai dapat memperbaiki struktur dari tekstur olahan pangan yang dihasilkan (Ketaren, 2008).

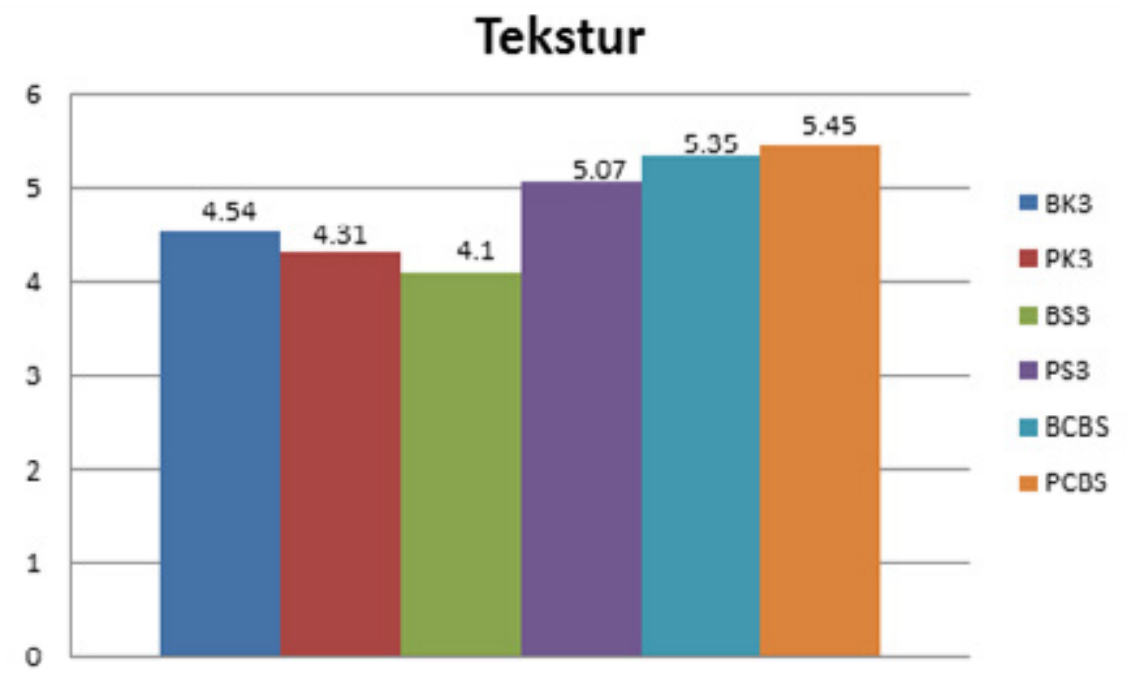

Gambar 3. Histogram Skor Keberterimaan Tekstur Produk Cokelat Spread dengan Penambahan Oleogel

\section{SIMPULAN}

Dari hasil penelitian dapat disimpulkan bahwa dari keenam formulasi cokelat spread (BS3,PS3, BK3, PK3, BCBS, dan PCBS) yang dihasilkan mengandung 23 jenis asam lemak (fatty acid dan fatty content) dengan masing masing karakterisik kimia yaitu nilai asam lemak diantaranya asam lemak Cis, Cis-10-Heptadecanoic Acid, C17:1, Cis-11,14-Eicosedienoic Acid, C20:2, Cis8,11,14-Eicosetrienoic Acid, C20:3n6 pada produk BK3 dan PK3 tetapi tidak terdapat pada BS3, PS3, BCBS, dan PCBS dan asam lemak Cis-13, 16-Docosadienoic Acid C22:2 terdapat pada produk cokelat spread PK3 dan BS3 tetapi tidak terdapat pada BK3, BS3, PS3, BCBS, dan PCBS sedangkan analisa cemaran logam As, Sn, $\mathrm{Cd}$, dan $\mathrm{Hg}$ pada produk cokelat spread yang dihasilkan menunjukkan nilai ratarata yang lebih kecil atau tidak terdeteksi dan memenuhi standar mutu SNI produk cokelat. Hasil terbaik dari uji sensori warna dan tekstur pada produk cokelat spread yaitu pada formula BCBS dengan skor 5,35 dan PCBS dengan skor 5,45 dengan tekstur yang lebih lembut, permukaan lebih 
mengkilap dan penampakan warna pada permukaan produk yang lebih bagus.

\section{DAFTAR PUSTAKA}

1. Arie, W., Nami, L., dan Mirna, I. 2015. Pengaruh Variasi Komposisi Lemak Cokelat, Olein Sawit dan Minyak Ikan Patin Terhadap Kandungan Nutrisi Cokelat Spread. Warta IHP. BBIA. Vol. 32 (2), 51-61

2. BSN. 2014. Cokelat dan Produk Cokelat. SNI 7934-2014. Badan Standardisasi Nasional. Jakarta

3. Bani,Ta.2018 Minyak Kedelai, slide share. net/tubachemiistry//minyak_kedelai.

4. BPOM. 2011. Badan Pengawas Obat dan Makanan. Peraturan Kepala BPOM No. HK.03.1.23.11.11. 09909. Tahun 2011 tentang Pengawasan Klaim dalam Label dan Iklan Pangan Olahan. http://www.bpom.go.id

5. Daming, W. dan Mamang. 2014. Tingkat Cemaran Timbal $(\mathrm{Pb})$ dan Kadmium (Cd) pada Pasta Cokelat yang Dihasilkan Balai Besar Industri Hasil Perkebunan. Jurnal Rekayasa dan Teknologi Industri Vol. 4, 6-11

6. Deannisa, M., Zulkifli, L., dan Mimi, N. 2014. Pembuatan Selei Cokelat Kulit Pisang Barangan. Jurnal Rekayasa Pangan dan Pertanian. Vol 2, No.2, 111-116

7. El-Hadad, N. M., Youssef, M. M., El-Aal, M. H. A., dan Abou-Gharbia, H. H. 2011. Utilisation Of Red Palm Olein In Formulating Functional Chocolate Spread. Journal Food Chemstry. 124, 285-290

8. Ginting, D. 2011. Pengaruh Substitusi Minyak Sawit dan Suhu Pemanasan Terhadap Mutu Selai Cokelat. Skripsi. Fakultas Pertanian. USU, Medan

9. Hariyadi, P. 2014. Mengenal Sawit dengan Beberapa Karakter. GAPKI. Wordpress: Jakarta

10. Isyanti, Mirna, dan Sumantri. 2012. Peneli-tian Pengembangan Pembuatan Produk Olahan Cokelat Spread (Chocolate Spread) Berbasis Sawit. Laporan Litbang BBIA, Bogor
11. Jansen, S. dan Sanggam D. R. T. 2002. Asam Lemak Trans dalam Makanan danPengarunhyaterhadap Kesehatan. Jurnal Teknologi dan Industri Pangan. Vol. XIII, No. 2, 184-188

12. Ketaren, S. 2008. Pengantar Teknologi Minyak dan Lemak Pangan. Cetakan kedua. Universitas Indonesia Press.: Jakarta

13. Marangoni, A. G. dan Garti, N. 2011. Edible Oleogels: Structure and Health Implications. Urbana: AOCS Pres.

14. Minifie. 1999. Chocolate and Confectionery: Science and Technology. 3rd Edition. Van Nostrand Reinhold: New York

15. Murry, R. K., Granner, Mayer, P., dan Rodwell, V. W. 2005. Biosintesis Asam Lemak. Editors. Biokimia. Jakarta

16. Ovesen, L., Leth, T., and Hans, K. 1998. Fatty Acid Composition and Content of Trans Monounsaturated Fatty Acids in Frying Fats, and Margarines, and Shortenings Marketed in Denmark. J.Am. Oil.Chem. SOC. 75 (9), 1079-1083

17. Ristanti, E. Y., Ramlah, S., Daming, W. 2017. Laporan Hasil Litbang Pembuatan Oleogel. BBIHP Makassar

18. Sartika, R. A. D. 2008. Pengaruh Asam Lemak Jenuh, Tidak Jenuh, dan Asam Lemak Trans terhadap Kesehatan. Jurnal Kesehatan Masyara-kat Nasional. Vol. 2, No. 4, 154-160

19. WHO and FAO. 2010. World Health Organization and Food Angriculture Organization. Fats and Fatty Acids in Human Nutrition Report and Expert Consultation in Food and Nutrition Paper. Vol. 91. Food and Agriculture Organization at the United Nations 20. Winarno, F. G. 1997. Kimia Pangan dan Gizi. Gramedia. Wordpress: Jakarta 